\title{
SKETSA TAHAPAN AWAL “MERARIK" AKRILIK 3D DENGAN MEDIA SENSOR SUARA DAN CAHAYA
}

\section{Christofer Satria $^{1^{*}}$, Hasbullah ${ }^{2 *}$, I Nyoman Subudiartha ${ }^{3^{*}}$}

\author{
Desain Komunikasi Visual, Fakultas Desain \\ Universitas Bumigora \\ Jl. Ismail Marzuki, No. 22 Cilinaya, Cakranegara, Kota Mataram, Kode Pos 83000 \\ Nusa Tenggara Barat. Indonesia \\ Email: chris@universitasbumigora.ac.id, hasbullah@universitasbumigora.ac.id, \\ subudiartha@universitasbumigora.ac.id
}

\begin{abstract}
Abstrak
Tradisi Merarik adalah salah satu adat istiadat dari suku sasak, yang berartikan kawin lari atau penculikan. Fenomena merarik ini sangatlah unik dikarenakan seorang pria harus menculik wanitanya tanpa diketahui oleh orang tua dari wanitanya. Dalam hal ini yang menjadi subjek penelitian berada di Desa Sade. Untuk mendapatkan informasi yang di inginkan peneliti menggunakan teknik wawancara dengan jenis penelitian kualitatif (Wawancara dengan Desa Adat (Desa Sade), Ketua Masyarakat Adat Sasak (MAS), dan Pasangan yang menikah dengan adat merarik). Hasil penelitian mendapati bahwa tahapan pertama dalam tradisi merarik ialah tahapan Merarik. Sketsa adalah gambar yang kasar dan ringan atau gambaran garis besarnya saja dari suatu gambar atau lukisan yang belum selesai. Atau sketsa dapat diartikan juga sebagai rencana dari suatu gambar atau lukisan yang akan dibuat. Metode Design Thinking adalah metode yang digunakan untuk penyelesaian masalah ini, yang terdapat beberapa tahapan seperti empathize, define, ideate, prototype, test, dan implement. Teori Estetika adalah teori yang digunakan untuk memperkuat hasil karya pencipta., Menurut Bruce Allsopp Teori estetika adalah teori yang mempelajari tentang proses dan aturan dalam menciptakan suatu karya seni, yang diharapkan bisa menimbulkan perasaan positif bagi orang yang melihat dan merasakannya. Pencipta berharap dengan adanya sketsa dari beberapa tahapan dalam merarik ini dapat membantu pencipta dalam mempermudah karya yang akan dibuat dan memberikan ide-ide tambahan kepada pencipta dan mempermudah pencipta untuk memilah atau memilih layer by layer dari sketsa tersebut.
\end{abstract}

Kata Kunci: merarik, kualitatif, akrilik, sketsa, estetika.

\begin{abstract}
The Merarik tradition is one of the customs of the Sasak tribe, which means eloping or kidnapping. This interesting phenomenon is very unique because a man has to kidnap his woman without being noticed by the parents of the woman. In this case, the research subject is in Sade Village. To obtain the desired information, researchers used interview techniques with this type of qualitative research (Interview with the Traditional Village (Sade Village), the Chairperson of the Sasak Indigenous Community (MAS), and a couple who married with the traditional merarik) The results of the study found that the first stage in the merarik tradition was the Merarik stage. A sketch is a rough and light drawing or just an outline of an unfinished drawing or painting. Or a sketch can also be interpreted as a plan for a picture or painting to be made. The Design Thinking method is the method used to solve this problem, which has several stages such as empathize, define, ideate, prototype, test, and implement. Aesthetic theory is a theory that is used to strengthen the work of the creator. According to Bruce Allsopp, Aesthetic theory is a theory that studies the processes and rules in creating a work of art, which is expected to generate positive feelings for people who see and feel it. The creator hopes that the sketch of several stages in this drawing can help the creator to simplify the work to be made and provide additional ideas to the creator and make it easier for the creator to sort or select layer by layer from the sketch.
\end{abstract}

Keywords: merarik, qualitative, acrylic, sketches, aesthetics.

\section{PENDAHULUAN}

Indonesia sebagai negara dengan masyarakat multietnis atau masyarakat dengan beragam latar belakang etnis, budaya dan adat istiadat. Hampir di setiap daerah terdapat suku, budaya dan adat istiadat dengan corak dan ciri khas daerah masing-masing. Salah satunya di pulau Lombok, Nusa Tenggara Barat (NTB), pulau ini memiliki suku Sasak yang memiliki tradisi unik yaitu tradisi "Merarik" (kawin lari). 
Gorga : Jurnal Seni Rupa

Volume 10 Nomor 02 Juli-Desember 2021

p-ISSN: 2301-5942 | e-ISSN: 2580-2380

Merarik dalam bahasa Sasak merupakan tindakan pranikah yang diawali dengan pelarian gadis (calon istri) dari pengawasan wali yang akan digunakan sebagai prosesi awal perkawinan. Merarik ada banyak mempunyai tafsiran sebagai proses melarikan diri dan ada juga yang menafsirkan sebagai perbuatan mencuri, dalam bahasa Sasak disebut menjauhkan anak perempuan dari pengawasan orang tuanya. Banyak pendapat lain tentang karakter-karakter yang ada dan penelitian sebelumnya tentang merarik (Adnan, 2004: 2) antaralain:

1. Berdasarkan informasi wawancara dari narasumber tentang sejarah adat-istiadat tradisi kawin lari (merarik) di pulau Lombok. Merarik dianggap sebagai adatistiadat budaya lokal yang merupakan ritual asli nenek moyang masyarakat suku Sasak Lombok yang dilaksanakan dan dilestarikan oleh masyarakatnya dan sudah ada sebelum adanya penjajahan dari kerajaan Bali dan penjajahan Belanda. Pendapat ini didukung oleh beberapa masyarakat suku Sasak yang dipelopori oleh para tokoh-tokoh adat terutama, "H. Lalu Azhar", salah satu tokoh ketua Masyarakat Adat Suku Sasak (MAS) dan beliau ialah mantan wakil gubernur NTB.

2. Peneliti Belanda, "Nieuwenhuyzen" mendukung pandangan ini. Menurut Nieuwenhuyzen, seperti dikutip dari Tim Depdikbud, banyak adat-istiadat suku Sasak yang memiliki kemiripan dengan adat-istiadat suku Bali, namun adat atau adat istiadat khususnya perkawinan Sasak adalah adat Sasak yang sejati. 3 . Menurut John Ryan Bartholomew, praktek kawin lari dipinjam dari budaya Bali.

Merarik memiliki beberapa tahapan, diantaranya: 1). tahap merarik $=>$ persetujuan pasangan untuk kawin lari atau perempuan biasa akan meninggalkan rumah secara diam-diam tanpa diketahui oleh keluarga. 2). masejati $\Rightarrow$ kegiatan melaporkan / memberikan informasi tentang terjadinya proses merarik. 3). Selabar $\Rightarrow$ Tahap awal hubungan keluarga calon mempelai pria dengan wanita. 4). Nuntut Wali => membahas hari baik akad nikah. 5). Ngawinang / Nikahang $=>$ pelaksanaan akad nikah. 6). Upacara Aji Krama Sorong Serah => Profesi tempat pelantikan perkawinan.

Berdasarkan penjelasan tentang merarik (kawin lari) dan melihat berbagai segi fenomena yang ada di dalamnya, pencipta ingin membuat "Sketsa Tahap Awal Proses Pembuatan Akrilik 3D Merarik Menggunakan Media Akrilik, Sensor Suara dan Cahaya" yang merupakan pengembangan dari paper cutting $3 d$.
Sketsa adalah gambaran yang kasar dan ringan atau sekedar garis besar dari gambar atau lukisan yang belum selesai. Sketsa juga dapat diartikan sebagai rencana pembuatan gambar atau lukisan (Allmy, 2012).

Pemotongan kertas 3d (paper cutting 3d) adalah kerajinan kuno yang praktek didalam terbentuk di seluruh dunia. Di beberapa budaya, hanya menggunakan kertas putih dan hitam, dilain sisi juga menggunakan kertas dan cat berwarna yang lebih disukai. Di beberapa budaya, pemotongan kertas hanya menggunakan gunting tetapi didalam budaya lain, banyak yang menggunakan pisau tajam. Dalam beberapa budaya, kertas dilipat sekali, dua kali, atau beberapa kali sebelum dipotong; di budaya lain, kertas tidak pernah dilipat (Dunne, 2018: 20-21).

Akrilik adalah plastik yang bentuknya seperti kaca. Namun, akrilik memiliki sifat yang membuatnya lebih unggul dari kaca. Salah satu perbedaannya adalah fleksibilitas yang dimiliki akrilik. Akrilik adalah bahan yang tidak rapuh, ringan, dan juga mudah dipotong, dikikir, dibor, digiling, dipoles atau dicat. Akrilik dapat dibentuk secara termal menjadi berbagai bentuk kompleks (Mclntyre, 2005: 167).

Penciptaan terdahulu ini menjadi salah satu acuan perancang dalam melakukan penciptaan sehingga perancang dapat memperkaya teori yang digunakan dalam mengkaji penciptaan yang dilakukan. Dari penciptaan terdahulu perancang tidak menemukan penciptaan dengan judul yang sama seperti judul penciptaan perancang. Namun perancang mengangkat beberapa penciptaan sebagai referensi dalam memperkaya bahan kajian pada penciptaan perancang. Berikut merupakan penciptaan terdahulu berupa beberapa jurnal terkait dengan penciptaan yang dilakukan pencipta. "Perancang dan Pembuatan Mesin Penekuk Akrilik" (Budiman, 2016). Perbedaan dari perancangan ini ialah dimana perancangan ini berfokus dalam pembuatan mesin penekuk akrilik yang digunakan untuk menekuk akrilik yang menghasilkan alat yang mampu menekukkan akrilik sudut 30-15derajat. 2"Pengaruh Komposisi Cat Akrilik dan Binder Sablon Terhadap Kualitas Tahan Luntur Warna dan Kekakuan dalam Pembuatan Motif Cosplay Pada Kain Katun, Satin, dan Drill” (Hadinata, 2019). Perbedaan dari perancangan ini ialah dimana perancangan ini berfokus pada pengaruh komposisi cat akrilik, binder sablon terhadap kualitas tahan luntur warna, kekakuan, komposisi yang memiliki ketahanan luntur warna terbaik. "3"Mesin Pemotong Akrilik Berbasis Mikrokontroler" (Putra, 2013). Perbedaan dari perancangan ini ialah dimana di perancangan ini 


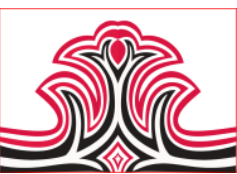

merancang sebuah mesin pemotong akrilik yang berbasis mikrokontroler yang digunakan untuk memotong akrilik sesuai dengan pola gambar yang dengan ralat $4 \mathrm{~mm}$ dan $2.6 \mathrm{~mm}$ untuk bagian dalam dan luar. Dari tiga perancangan terdahulu makan dapat disimpulkan bahwa penciptaan yang akan diciptakan oleh pencipta mempunyai perbedaan yang sangat jauh, dan penciptaan ini berfokus pada pengembangan paper cutting $3 d$ yang menggunakan akrilik $3 \mathrm{~d}$ sebagai bahan pembuatan penciptaan ini.

Penjelasan diatas maka pencipta dapat menyimpulkan bahwa kreasi ingin membuat sketsa tahap awal menggambar untuk membantu pencipta mempermudah pekerjaan yang akan dibuat dan memberikan tambahan ide kepada pencipta dan pencipta dapat memilah atau memilih. lapis demi lapis dari sketsa untuk dikembangkan lagi.

\section{KAJIAN TEORI}

\section{Teori Estetika}

Teori estetika adalah teori yang digunakan untuk memperkuat karya pencipta. Menurut Bruce Allsopp, Teori Estetika adalah teori yang mempelajari proses dan aturan didalam menciptakan suatu karya seni, yang dapat menimbulkan perasaan positif bagi orang yang melihat dan merasakannya. (Sumardjo, 2010: 4).

\section{Definisi Merarik}

Secara etimologis, merarik berasal dari kata lari dalam bahasa Sasak. Merarinang artinya pergi atau dalam bahasa Indonesia lari yaitu laki-laki lari dari perempuan untuk dijadikan istri (Saladin, 2013: 23). Istilah merarik yang artinya kawin lari sangat banyak ditemui di pulau Lombok, meskipun begitu di beberapa tempat istilah tersebut berbeda karena perbedaan perpepsi masing-masing desa yang memiliki jenis penafsiran yang berbeda-beda.

Merarik merupakan budaya khas suku Sasak dalam memulai memilih pasangan untuk menikah dan berkeluarga. Praktik ini tersebar di seluruh pulau Lombok, namun di beberapa tempat ada penyebutan istilah merarik yang berbeda. Di Kecamatan Ampenan, suku Sasak memberikan istilah marari (Adnan, 2004: 2).

\section{Definisi Sketsa}

Sketsa adalah gambaran kasar dan ringan atau hanya garis besar dari gambar atau lukisan yang belum selesai. Atau sketsa juga bisa diartikan sebagai rencana gambar atau lukisan yang akan dibuat nantinya. Sketsa temporer dibuat dengan menggunakan kertas atau kanvas. Sehingga dapat dikatakan bahwa membuat
Gorga : Jurnal Seni Rupa

Volume 10 Nomor 02 Juli-Desember 2021

p-ISSN: 2301-5942 | e-ISSN: 2580-2380

sketsa sebelum menggambar merupakan kegiatan yang mendasar dan penting untuk melatih ketrampilan, sekaligus untuk meminimalisir kesalahan-kesalahan yang akan dibuat oleh pembuat (Allmy, 2012). Pengertian Sketsa Menurut Para Ahli:

\section{1). Menurut Linda Murray dan Peter}

Sketsa adalah desain kasar dari suatu komposisi yang dibuat untuk kepuasan pribadi. Ada beberapa hal dalam kepribadian seniman yang sngat erat atau penting yaitu: skala, perbandingan, komposisi, eksposur dan lain sebagainya (MT, $2018: 36$ ).

\section{2). Menurut H.W Flowler}

Sketsa begitu saja tanpa persiapan, gambaran kasar, ringan, dan hanya garis besar dari lukisan atau deskripsi pendahuluan (Fidelia, 2009 :18).

\section{3). Menurut But Muchtar}

Sketsa ialah ekspresi yang paling esensial, yang berfungsi sebagai media dalam proses kreatif tetapi sekaligus sebagai pembuatan sebuah karya (Eko, 2019: 11).

\section{4). Definisi Paper Cutting 3D}

Paper Cutting $3 d$ adalah kerajinan kuno yang terdapat berbagai di seluruh dunia. Di beberapa budaya, biasanya hanya menggunakan kertas putih dan hitam. Paper cutting hanya dilakukan dengan gunting tetapi di dalam budaya lain, pisau tajam juga dapat digunakan. Dalam beberapa budaya, kertas dilipat sekali, atau lebih Adapun di budaya lain, kertas tidak pernah dilipat (Melichson, 2009: 8). Contoh Paper Cutting 3D: 

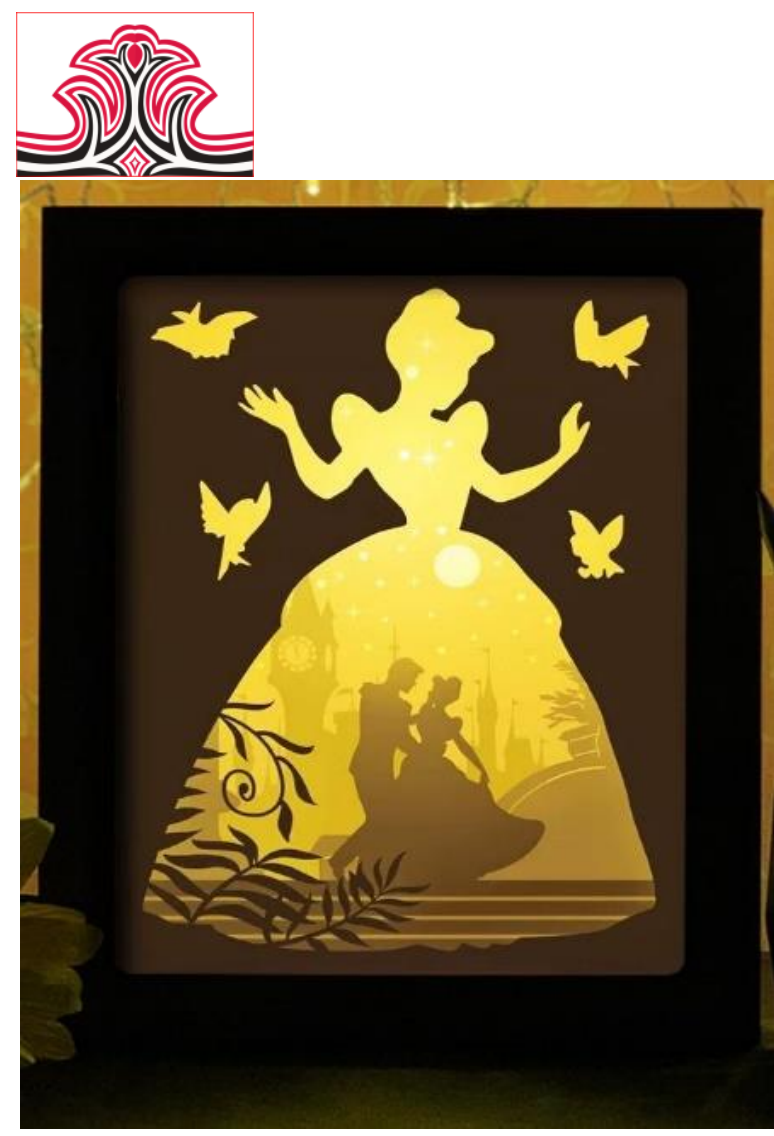

Gambar 1. Contoh Peper Cutting 3D

(Lightboxgoodman.com, 2021)

Dilihat dari gambar diatas, peneliti ingin mencoba membuat kreasi baru dimana membuat paper cutting $3 d$ menggunakan media akrilik.

\section{5). Definisi Akrilik}

Akrilik adalah plastik yang bentuknya seperti kaca. Akrilik memiliki beberapa sifat yang membuatnya lebih unggul dari kaca. Salah satu perbedaannya adalah fleksibilitas yang dimiliki oleh akrilik. Akrilik adalah bahan yang tidak mudah rapuh, ringan, dan juga mudah dipotong, dikikir, dibor, digiling, dipoles atau dicat. Akrilik dapat dibentuk secara termal menjadi berbagai bentuk kompleks (Mclntyre, 2005: 167). Akrilik ada 3 macam, diantaranya:

\section{(1). Resin Akrilik}

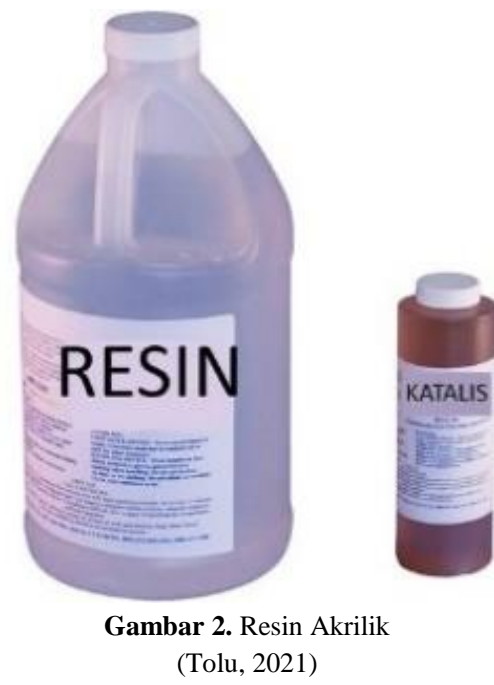

Gorga : Jurnal Seni Rupa

Volume 10 Nomor 02 Juli-Desember 2021 p-ISSN: 2301-5942 | e-ISSN: 2580-2380

\section{(2). Akrilik Transparan}

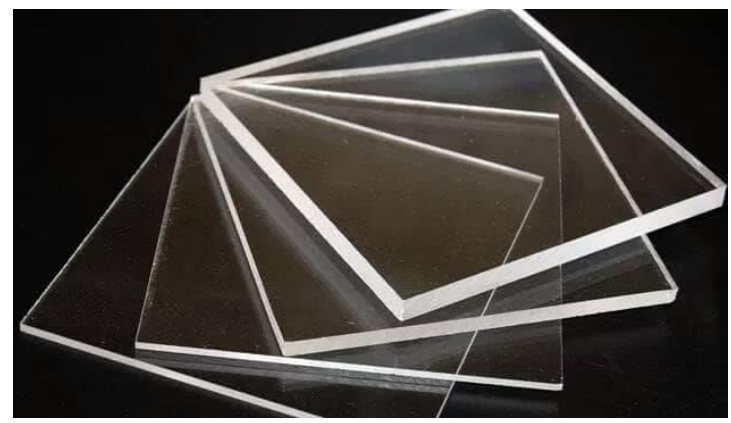

Gambar 3. Akrilik Transparan

(Caraousell, 2021)

\section{(3). Akrilik Susu}

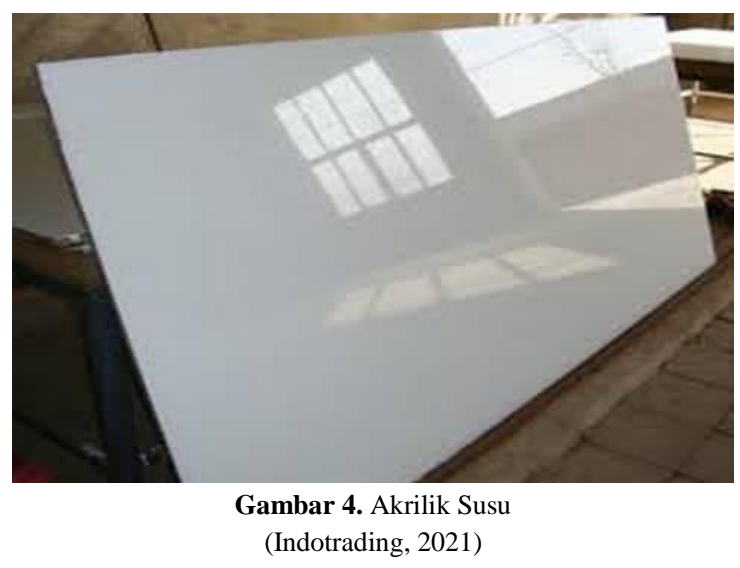

Berdasarkan 3 akrilik di atas, peneliti memilih akrilik susu untuk dijadikan bahan kreasi.

\section{METODE PENELITIAN}

\section{Metode Kualitatif dan Design Thinking}

Penelitian ini menggunakan metode kualitatif. Nasution (2003) menjelaskan bahwa desain penelitian kualitatif tidak dapat ditentukan sebelumnya. Masalah yang umum pada proses awal dan pada hal yang spesifik. Tujuan penelitian kualitatif bukan untuk menguji atau membuktikan suatu teori, tetapi disini teori kualitatif ini diperoleh dari data-data yang dikumpulkan oleh peneliti di lapangan.

Selain itu, pencipta juga menggunakan metode Design Thinking sebagai metode dalam tahapan pembuatan kreasi ini dimana design thinking merupakan proses iteratif dimana peneliti harus memahami pengguna, mendefinisikan kembali masalah dalam mengidentifikasi alternatif strategi dan solusi yang mungkin tidak terlalu terlihat dengan pemahaman awal. kita. Design Thinking memberikan banyak sekali pendekatan berbasis solusi untuk memecahkan masalah-masalah yang ada. (Dunne, 2018: 20-21). 


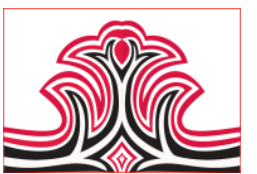

\section{HASIL DAN PEMBAHASAN}

\section{Hasil}

Tahap pertama adalah tahap penarikan dimana pada tahap ini seorang perempuan secara diam-diam meninggalkan rumahnya atau terjadi proses penculikan calon laki-laki.

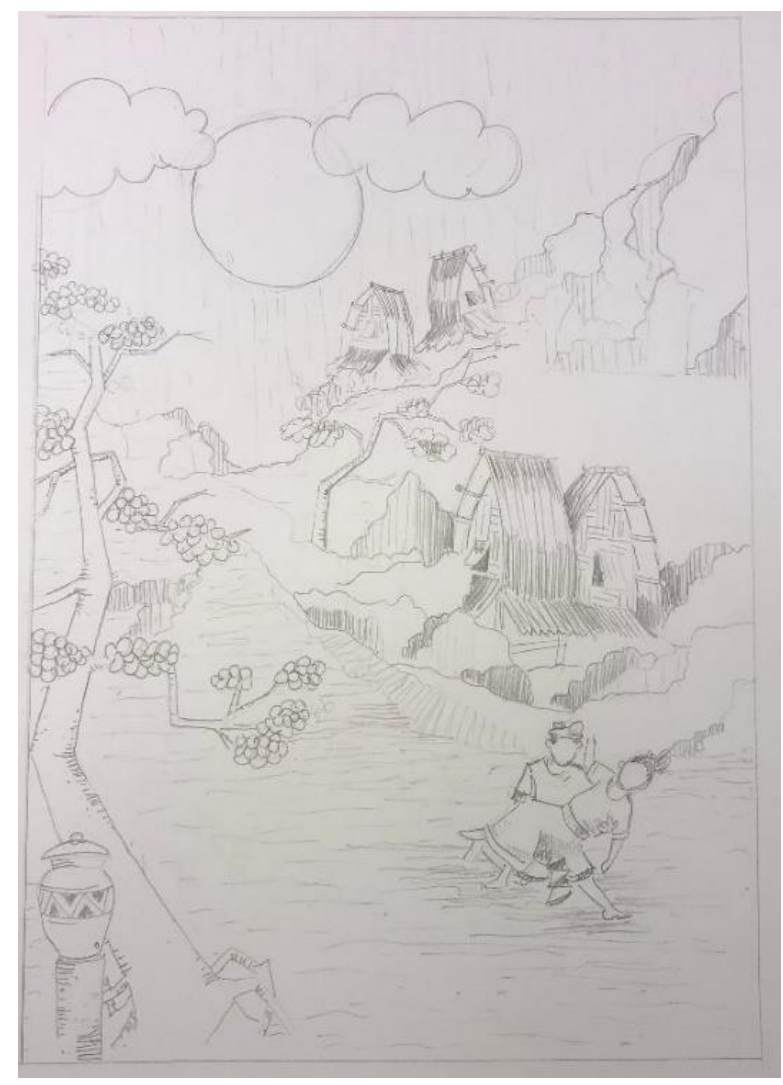

Gambar 5. Sketsa Awal Merarik

(Satria, 2021)

Bertolak sketsa di atas menggambarkan seorang lakilaki menculik perempuan atau pasangannya dari rumahnya (kawin lari), dari situ sketsa ini akan disortir lagi dan dipotong menurut lapis demi-lapis sehingga tampak 3d saat diaplikasikan pada kreasi berikutnya. Maka dari gambar ini dibuat lapis demi lapis yang menjadi:
Gorga : Jurnal Seni Rupa

Volume 10 Nomor 02 Juli-Desember 2021 p-ISSN: 2301-5942 | e-ISSN: 2580-2380

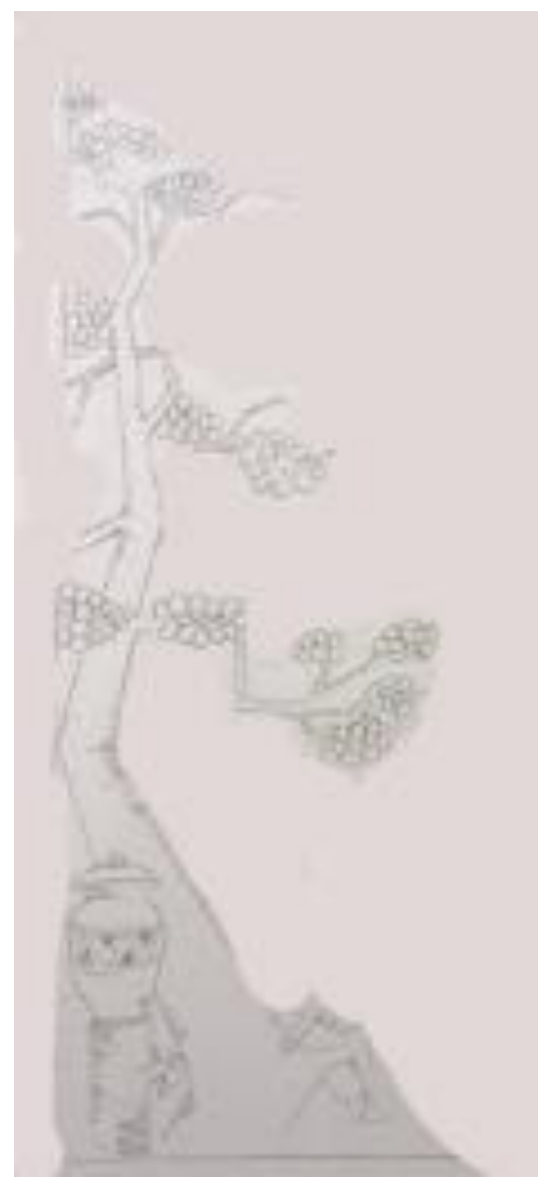

Gambar 6. Layar Pertama (Satria, 2021)

Lapisan ini kita bisa melihat sebuah pohon yang memiliki kendi berisi air yang biasa digunakan oleh sebagian besar masyarakat suku Sasak.

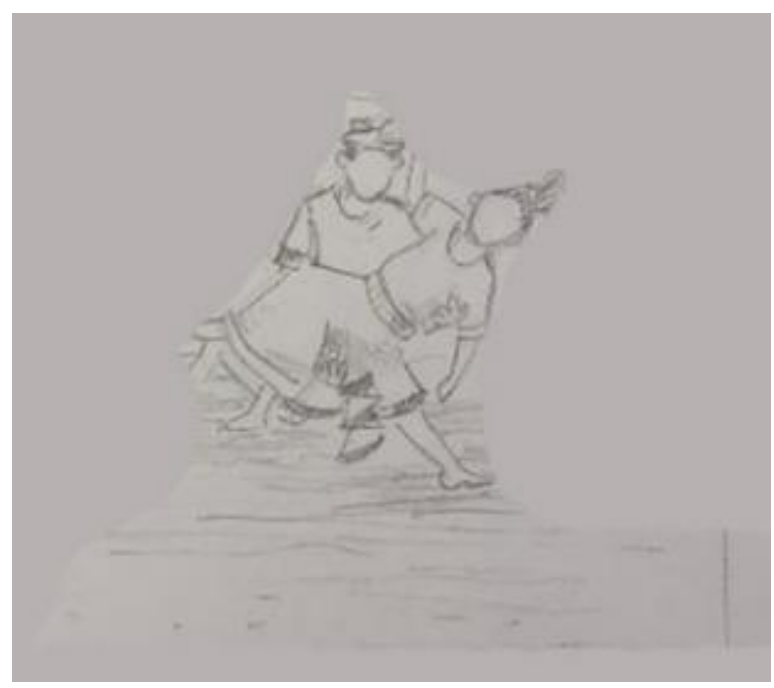

Gambar 7. Layar Ke-dua (Satria, 2021)

Dimana pada lapisan ini ada sketsa laki-laki yang mencuri perempuan pasangannya atau merampas pasangannya dari rumahnya (kawin lari). 


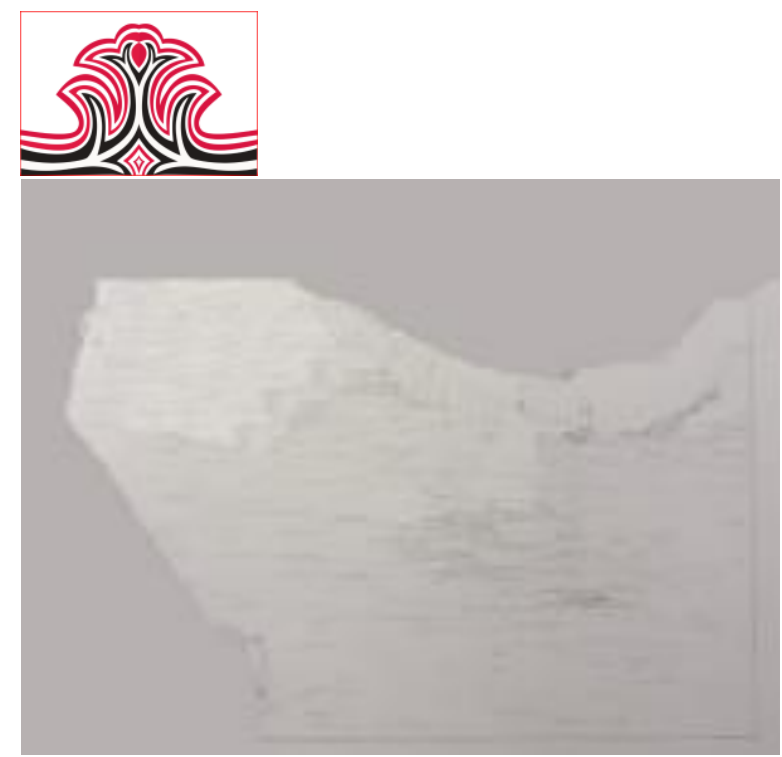

Gambar 8. Layar Ke-tiga

(Satria, 2021)

Sketsa ini menunjukkan latar belakang baground dari lapangan di desa.

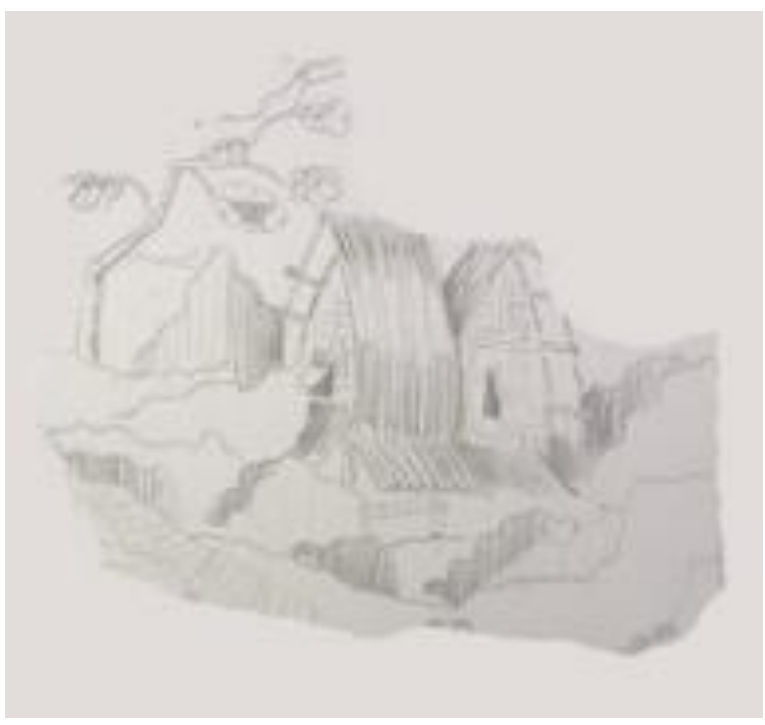

Gambar 9. Layar Ke-empat

(Satria, 2021)

Sketsa ini memperlihatkan pemandangan sebuah desa suku Sasak "Lumbung" yang merupakan ciri khas rumah adat suku Sasak.

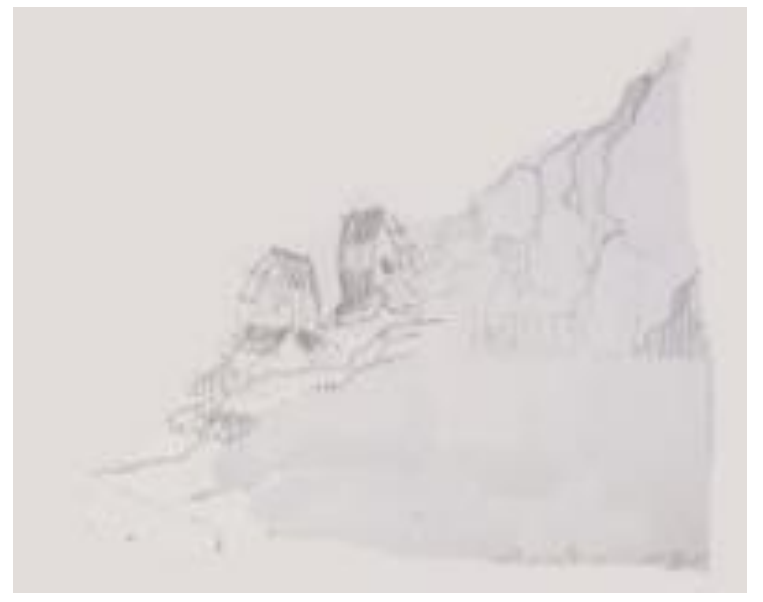

Gambar 10. Layar Ke-lima (Satria, 2021)
Gorga : Jurnal Seni Rupa

Volume 10 Nomor 02 Juli-Desember 2021

p-ISSN: 2301-5942 | e-ISSN: 2580-2380

Sketsa tersebut terlihat pemandangan pegunungan dan desa-desa yang biasanya berupa pedesaan di kaki gunung.

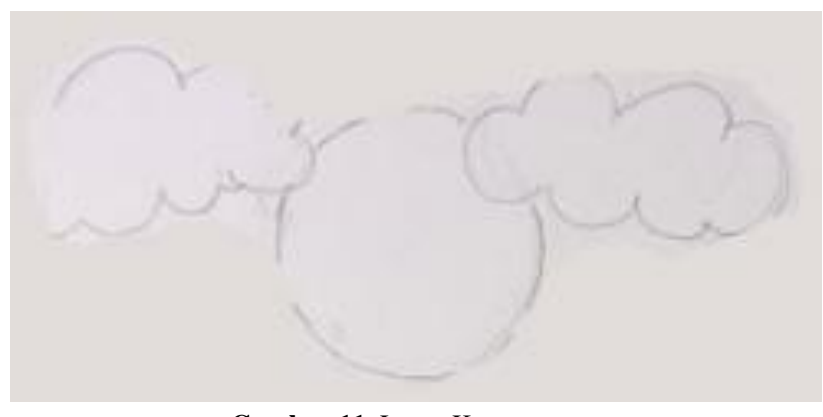

Gambar 11. Layar Ke-enam (Satria, 2021)

Sketsa bulan ini karena sebagian besar fenomena kawin lari atau penculikan perempuan dilakukan pada malam hari, atau fenomena di mana orang tua mengetahui bahwa anaknya tidak hadir atau tidak pulang hingga larut malam.

\section{Pembahasan}

1. Sketsa diatas adalah salah satu tahapan dari merarik (kawin lari) yang adalah salah satu tahapan adat istiadat dalam pernikahan di suku Sasak, yang dimana di sketsa ini adalah tahapan pertama yang menceritakan seorang pria atau calaon pengantin pria harus menculik calon pengantin perempuan untuk membuktikan kepada calon perempuan bahwa dia adalah seorang pemberani. Selain itu didalam sketsa ini, peneliti memilah-milah gambar menjadi 6 bagian yang akan di aplikasikan kedalam akrilik 3d. Setiap gambar didalam sketsa ini mempunyai arti dan makna yang masi bersangkutan erat dengan adat-istiadat suku sasak yaitu: 1). Seorang pria yang menculik wanitanya $\Rightarrow$ di gambar ini memiliki makna bahwa seorang pria harus membuktikan kepada calon pengantinnya bahwa dia seorang berani dan berani untuk membawa lari calon pengantinnya. 2). Pohon dan kendi $\Rightarrow>$ yang empunyai makna bahwa sebagian besar masyarakat suku sasak menggunakan kendi sebagai salah satu adat istiadat, yang dimana kendi tersebut biasanya digunakan untuk mengambil air atau sebagai tempat minum dan tempat cuci tangan. 3). Lembah atau kaki gunung $=>$ dimana biasanya desa-desa yang melakukan adat-istiadat merarik ini lebih banyak berada di kaki gunung atau desa-desa terpencil. 4). Rumah adat lumbung padi $\Rightarrow$ dimana gambar rumah-rumah disesuaikan dengan rumah suku adat sasak yaitu lumbung padi. 5). Bulan $\Rightarrow$ yang memberikan kesan malam hari, dikarenakan dari adat suku sasak seorang pria harus mencuri pasangannya dimalam hari, selain itu ada beberapa adat istiadat yang akan menikahkan 
anak perempuannya jika tidak pulang hingga malam hari.

Dari keterangan diatas maka dapat disimpulkan bahwa sketsa tahapan awal ini menceritakan adat-istiadat suku sasak yang dimana di tahapan awal adalah taharapn merarik yang dimana seorang pria harus berani menculik calon pengantinnya tanpa diketahui oleh orang tua dari pihak perempuan, selain itu didalam sketsa ini juga memberikan beberapa gambaran pendukung seperti bulan, lumbung padi, lembah atau kaki gunung untuk lebih menjelaskan adat istiadat suku sasak tersebut.

\section{KESIMPULAN DAN SARAN}

\section{Kesimpulan}

Didalam penelitian ini, Peneliti berispirasi dan mengembangkan penelitian ini dari papercutting $3 \mathrm{~d}$. Dari ispirasi ini maka peneliti mencoba mengembangkan dengan membuat akrilik 3d. Didalam sketsa tahapan awal "merarik" akrilik $3 \mathrm{~d}$ ini membahas secara khusus tentang sketsa tahapan awal dari adatistiadat suku Sasak Lombok yang dimana tahapan awal itu ialah tahapan merarik, yang menceritakan calon perempuan akan meninggalkan rumah secara diamdiam tanpa diketahui oleh keluarga dan juga memiliki fenomena dimana calon pria harus membuktikan kepada calon pengantinnya akan keberaniannya dengan cara menculik atau membawa lari pasangannya. Dari keunikan adat-istiadat dan fenemona yang terjadi maka peneliti membuat sketsa tahapan sketsa ini, pencipta sangat berharap dengan adanya sketsa pertama tahapan dalam merarik dapat membantu peneliti untuk mengembangkan kembali tahapan-tahapan berikutnya dan dapat mempermudah pencipta untuk memilahmilah sketsa yang akan diaplikasikan kedalam akrilik 3d. Selain itu pencipta juga berharap dengan adanya sketsa awal merarik ini dapat memperkenalkan kepada masyarakat luas tentang keunikan adat istiadat pernikahan suku Sasak Lombok dan menambah wawasan tentang adat-istiadat Lombok khusunya dalam tahapan merarik.

\section{Saran}

Pembuatan sketsa tahapan awal ini masi banyak kekurangan, terlebih dalam hal teknis atau gambaran yang kurang serta makna yang kurang dipahami oleh masyarakat. Selain itu pada prosesnya ini hanyalah sketsa tahapan awal dan masi ada lima tahpan lagi yang belum dibuat atau diaplikasikan. Rencana proses aplikasi pun akan mundur beberapa kali dikarenakan situasi yang kurang kondusif saat ini. Meskipun begitu pembuatan sketsa ini dapat dikembangkan lebih lanjut oleh para seniman dan akademisi untuk membuat perkembangan sketsa dari tahapan-tahapan lainnya didalam merarik.

\section{UCAPAN TERIMA KASIH/PENGHARGAAN}

1. Istri dan anak tercinta,

2. Kepada Institusi tempat saya bekerja Universitas Bumigora yang sudah mensupport,

3. Teman-teman seangkatan S3 ISI Denpasar,

4. Teman-teman dosen DKV Universitas Bumigora yang sudah banyak membantu dalam penciptaan ini, dan

5. Dan Semua yang sudah membantu dalam penciptaan ini.

\section{DAFTAR RUJUKAN}

Adnan, S. (2004). Pergeseran Nilai-nilai Adat Marari Pada Masyarakat Suku Sasak Lombok (Studi Pada Kecamatan Ampenan, Kota Mataram, Provinsi Nusa Tenggara Barat). Semarang: Program Pascasarjana Universitas Diponegoro.

http://eprints.undip.ac.id/11011/1/2004MNO T3051.pdf

Allmy. (2012). Pengertian Sketsa. http://allmy.blogdetik.com/2012/12/24/pengerti ansketsa/ (diakses 18 Maret 2021).

Azhar, H. Lalu. (2021). "Tradisi Merarik". Hasil Wawancara Pribadi: 12 April 2021, Desa Sade.

Budiman, H. C. (2016). Perancangan dan Pembuatan Mesin Penekuk Akrilik. Yogyakarta: Universitas Islam Indonesia.

Caraousell. (2021). Acrylic Sheet. https://www.carousell.sg/p/acrylic-sheet-5mmthk-108794231/ (diakses pada tanggal 16 Juni 2021).

Dunne, David. (2018). Design Thinking at Work. London: University of Toronto Press.

Eko, S. (2019). Gambar Bentuk. Padang: Universitas Negeri Padang.

Fidelia, M. (2009). Perpustakaan Seni Rupa di Yogyakarta (Intergrasi Perpustakaan, Galeri, dan Kafe, dengan Memasukan Karakter Karya-karya Dimitri Maksimov sebagai Sumber Inspirasi). Yogyakarta: Universitas Islam Indonesia.

Hadinata, G. Q. (2019). Pengaruh Komposisi Cat Akrilik dan Binder Sablon Terhadap Kualitas Tahan Luntur Warna dan Kekakuan Dalam Pembuatan Motif Cosplay Pada Kain Katun, Satin, dan Drill. Yogyakarta: Universitas Negeri Yogyakarta.

Indotrading. (2016). Acrylic Lembaran Putih Susu $3 \mathrm{~mm}$. https://www.indotrading.com/cahayaabad ipackinggasket/acrylic-lembaran-putih- 
p606771.aspx (diakses pada tanggal 16 Juni 2021).

Lightboxgoodman. (2021). Cinderella 4 - Paper Cutting Light Box.

https://lightboxgoodman.com/collections/allproducts/products/across-the-sea-1-laser-cutreproduction-3d-paper-cutting-night-lightpaper-cut-light-box-paper-cutting-light-box1 ? variant $=39262773903522 \quad$ (diakses pada tanggal 16 Juni 2021).

Mclntyre, J. E. (2005). Synthrtic Fibres: Nylon, Polyster, Acrylic, Polyolefin. England: Woodhead Publishing Limited.

Melichson, H. (2009). The Art Of Paper Cutting. USA: Penn Publishing.

MT, F. S. H. (2018). Pengaruh Penggunaan Media Grafis Terhadap Kemampuan Representasi Matematis Siswa Di Kelas VII Mts N 4 Mandailing Natal. Padangsidimpuan: IAIN Padangsidimpuan.

Nasution. (2003). Metode Penelitian Naturalistik Kualitatif. Bandung: Tarsito.

Putra, P. A. (2013). Mesin Pemotong Akrilik Berbasis Mikrokontroler. Salatiga: Universitas Kristen Satya Wacana.

Satria, C. (2021). "Merarik". Hasil Dokumentasi Pribadi: 16 Juni 2021, Universitas Bumigora.

Saladin, B. (2013). Tradisi Merari'Suku Sasak di Lombok dalam Perspektif Hukum Islam. AlIhkam, 8(1), 21-39. http://doi.org/10.19105/al-ihkam.v8i1.338

Sumardjo, J. (2010). Estetika Nusantara. Surakarta: Institut Seni Indonesia Surakarta.

Tolu, Admin. (2017). Pengenalan Resin dan Katalis serta Takaran Tepat Perbandingannya. https://www.kerajinankreatif.com/2017/04/cam puran-resin-dan-katalis.html (diakses pada tanggal 16 Juni 2021). 